\title{
Completeness of MCCD and Accuracy of Underlying Cause of Death
}

\author{
Titin Wahyuni* and Dyah Rachmadhani \\ Sekolah Tinggi Ilmu Kesehatan Yayasan RS. Dr. Soetomo, Indonesia \\ Jalan Karang Menjangan No.12, Airlangga, Gubeng, Kota Surabaya, Jawa Timur 60286 \\ *Corresponding author: wtitin.2012@gmail.com
}

\begin{abstract}
Background Medical certification of cause of death (MCCD) is being issued on every death occasion in every hospital of Indonesia. MCCD consists of two part; part 1 would record with those conditions in the causal link that leading to death and part 2 would fill with other condition that significant in contributing to death. Leading cause of death are defined as Underlying Cause of Death (UCoD). UCoD is located on the Ic section of particular MCCD that have been used by selected hospital for this research. On the other hand, The Indonesian Vital Registration (VR) system relies on information of UCoD. The quality of it might varies considering to a medically qualified doctor who record it. Objctive In this paper, we focused examining the effect of completeness of MCCD to accuracy of $U C o D$ by reggresion ordinal. Methode We taken a total sample from inpatient of death data in January to April 2017, founded 106 MCCDs to analyse and only 58 ones that recorded with UCoD. Result The result suggest that there is a significant effect the completeness of MCCD to accuracy of UCoD. Moreover, We were found : 15 UCoD were stated very accurate, 11 were stated quite accurate and 32 stated not accurate. Conclusion, it needs a commitment from doctors and hospital should be monitoring the completeness of MCCDs and update certain skill to produce high quality of $U C o D$ in order improving VR system.
\end{abstract}

Keywords: Completeness; MCCD; Accuracy; UCoD; Hospital

\section{INTRODUCTION}

Hospital as one of the health service facilities is part of the health resources that are needed in supporting the implementation of health efforts, and the development of mortality statistics that are beneficial to national development. Each hospital has the obligation to record and report on all activities of the hospital in the form of hospital management information system. International Classification of Disease (ICD) -10 is a classification system of diseases classified by international standards for the purposes of the statistical health of a region or country. The cause of death data compiled based on ICD-10 is a data source that can be used to calculate life expectancy, mortality by cause and age. Availability of such data is part of Health Information System. The World Health Organization (WHO) prepares the Medical Certification Cause of Death (MCCD), the primary source of mortality data. The death certificate information can be obtained from a health worker (hospital doctor or a primary health service's doctor) or for accidents / violence cases from police and forensic doctors. For some cases related to law, forensic physicians are responsible for the completeness of death certificates. Therefore, this study was conducted to evaluate the underlying cause of death in medical records at Inpatient of selected hospital. 


\section{METHOD}

The type of this research is descriptive research which describes the underlying cause of inpatient deaths at RSU Haji Surabaya in January-April 2017, with a retrospective approach. The population in this study is all RM patients died inpatient at RSU Haji Surabaya in January-April 2017. In this study the researchers used the total sampling because the entire population is used as the object under study.

\section{RESULT AND DISCUSSION}

Table 1 Comparison between completeness MCCD and MCCD accuracy

\begin{tabular}{|c|c|c|c|c|c|c|c|}
\hline \multirow[b]{2}{*}{ MCCD category } & \multicolumn{7}{|c|}{ MCCD accuracy } \\
\hline & $\begin{array}{r}\text { Very acc } \\
\%\end{array}$ & & $\begin{array}{c}\text { Quite } \\
\text { accurate }\end{array}$ & $\%$ & $\begin{array}{c}\text { Not } \\
\text { accurate }\end{array}$ & $\%$ & Total \\
\hline Very complete & 9 & 60 & 4 & 36,36 & 20 & 25,00 & \\
\hline Quite complete & 6 & 40 & 6 & 54,55 & 11 & 13,75 & \\
\hline Not complete & 0 & 0 & 1 & 9,09 & 49 & 61,25 & \\
\hline Total & 15 & 100 & 11 & 100 & 80 & 100 & 106 \\
\hline
\end{tabular}

As seen as table 1 in the column is very accurate the completeness of the high then the accuracy of the figures to be high as well, followed by the column is accurate then the higher completeness will make the number of accuracy to be high as well. Unlike the case with inaccurate columns, it is inaccurate but the complete number of completeness occurs because I (c) in SMPK is filled and not accurate because I (c) is not equal to I (d), then in quite complete it is not accurate because in I (c) is filled but the appeasement with I (d) is not specific e.g. in I (c) DM + AKI while in I (d) DM and the last one is incomplete is not accurate because I (c) c) and I (d) cannot be compared.

\section{CONCLUSION}

The result of UCoD's accuracy analysis compared with UCoD in selected hospital is very accurate $25,86 \%$, accurate enough $18,97 \%$ and not accurate equal to $55,17 \%$; the completeness MCCD has an effect on MCCD accuracy.

\section{REFERENCES}

Hatta, GR. (2010). Pedoman Manajemen Informasi Kesehatan di Sarana Pelayanan Kesehatan. Jakarta: UI-PRESS

Komalasari, L. (2014). Tinjauan Kelengkapan Pengisian Formulir Sertifikat Medis Penyebab Kematian Di RSUP Fatmawati Jakarta. Skripsi. Tidak dipublikasikan. Jakarta: Universitas Esa Unggul.

Nurryati. H,T. (2014). Evaluasi Ketepatan Kode Diagnosis Penyebab Dasar Kematian Berdasarkan ICD-10 Di RS Panti Rapih Yogyakarta. Jurnal Manajemen Informasi Kesehatan Indonesia. Volume 2 (1). 82-89.

Pratiwi, YE. (2010). Ketepatan Penentuan Kode Penyebab Dasar Kematian Pasien di Rumah Sakit Umum Daerah Kota Salatiga Triwulan IV Tahun 2010. Jurnal Manajemen Informasi Kesehatan Indonesia. 89-96. 